\title{
Inflammatory and Immunological parameters in adults with Down syndrome
}

\author{
Maria BF Trotta ${ }^{1 *}$, João B Serro Azul', Mauricio Wajngarten'1, Simone G Fonseca', Anna C Goldberg ${ }^{2}$ and \\ Jorge E Kalil ${ }^{1}$
}

\begin{abstract}
Background: The increase in life expectancy within the general population has resulted in an increasing number of elderly adults, including patients with Down syndrome (DS), with a current life expectancy of about 50 years. We evaluate the parameters of humoral and cellular immune response, the quantitative expression of the regulator of calcineurin1 gene (RCAN1) and the production of cytokines. The study group consisted of adults DS $(n=24)$ and a control group with intellectual disability without Down syndrome (ID) $(n=21)$ and living in a similar environmental background. It was evaluated serology, immunophenotyping, the quantitative gene expression of RCAN1 and the production of cytokines.

Results: In the DS group, the results showed an increase in NK cells, CD8, decreased CD19 $(p<0.05)$ and an increase spontaneous production of IFNgamma, TNFalpha and IL-10 $(p<0.05)$. There was not any difference in RCAN1 gene expression between the groups.

Conclusions: These data suggest a similar humoral response in the two groups. The immunophenotyping suggests sign of premature aging of the immune system and the cytokine production show a proinflammatory profile.
\end{abstract}

\section{Introduction}

The increase in life expectancy of the general population has resulted in an increasing number of elderly adults, including patients with Down syndrome (DS), with a current life expectancy of about 50 years [1]. The death causes in adults with DS are different from the ones of the general population. Alzheimer's disease (AD), congenital heart defects, aspiration, pneumonia are among the most frequent when compared to solid tumors and ischemic heart disease [2-6]. The association with leukemia decreases with age and it is not apparent after the age of 40 [1]. Older DS have an increased susceptibility to infections. However, most individuals with this syndrome do not show clear features of immunological diseases. Many of these immunological alterations are agerelated changes and can be enclosed in the spectrum of multiple signs of early senescence, which is characteristic of the DS [7]. The immunological response varies in the aging process. In children over the age of 6 , the

\footnotetext{
* Correspondence: mbfortunato1@hotmail.com

${ }^{1}$ Heart Institute University of São Paulo Medical School, São Paulo Full list of author information is available at the end of the article
}

absolute number of IgG and IgA increases. IgM rates decrease in adolescence and throughout the aging process, there is a low number of circulating B cells (CD19), a decrease of CD4+, an increase of CD8 and NK cells. In DS, granulocyte apoptosis is accelerated in various conditions. T-cells with the early apoptotic phenotype were increased in cell cultures from DS children $[8,9]$. The response against vaccinal antigens and other antigens such as pertussis, rubella, measles, hepatitis A and B was better in DS patients when compared with other groups [10-14]. However other studies disagree with this affirmation [15-18].

It was proposed a model suggesting that, in Down syndrome, the overexpression of chromosome 21 encoded gene products leads to an impairment of the immunological response [19]. However, there are few studies about immunological parameters in older adults with DS. This extra copy of HSA21 may be responsible for the increased expression of many genes encoded on this chromosome. The trisomy of chromosome 21 is characterized by multiple signs of early senescence which justify its inclusion within the group of 
"segmental progeroid syndromes," defined as those genetic disorders in which multiple major aspects of the senescent phenotype appear $[20,21]$. The regulator of calcineurin 1 gene, RCAN1, is present in the specific region in the HSA21 that was described as containing the genes responsible for phenotypic characteristics of the syndrome. The RCAN1 gene product interacts physically with calcineurin $\mathrm{A}$, a catalytic subunit of the $\mathrm{Ca}$ $(2+) /$ calmodulin-dependent protein phosphatase PP2B and inhibits its activity [22]. The dephosphorylation of the nuclear factors of activated T cells (NFATs) by calcineurin is essential for activating cytokine gene expression and, consequently, the immune response. Although the effects of RCAN1 on the immune system have not yet been directly examined, the therapeutic benefits of other calcineurin inhibitors have been examined in a variety of conditions [23]. Current immunosuppressive protocols are based mainly on the administration of the calcineurin enzyme inhibitors cyclosporine A and FK506 [24]. The RCAN1 gene consists of seven exons, four of which (exons 1-4) can be alternatively spliced to produce a number of different mRNA isoforms, since exons 5-7 are likely to be common in each mRNA isoform. These isoforms may have different expression patterns, functions and regulation mechanisms. The expression of exon 2 was detected in fetal, but not adult, human brain and calcineurin can induce the expression of RCAN1 isoform 4 mRNA, but it does not induce the other isoforms [25]. There is no study examining the quantitative expression of RCAN1 in adults with DS and its association with cytokines production. The purpose of this study was to evaluate the aspects of humoral and cellular responses, as well as, to look into the quantitative expression of the calcineurin1 (RCAN1) regulator with relation to cytokine production in peripheral mononuclear cells in adults with DS and the ones with intellectual disabilities (ID) due to other causes and who were monitored in the same institution, Associação de Pais e Amigos dos Excepcionais (APAE-SP).

\section{Results}

\section{1) Serology}

The IgG, IgA, IgM, cRP, ASO frequencies and the complement fraction $(C 3, C 4)$ were similar in the serum of both groups analyzed. Similarly, there were no difference in the antibody levels against cytomegalovirus, mononucleosis, toxoplasmosis and hepatitis B antigens, measles and rubella vaccines $(\mathrm{p}>0.05)$ (Table 1$)$.

\section{2) Immunophenotype}

The CD3 and CD14 percentages were similar in both groups. The results showed lower percentage of B lymphocytes (CD19+) in DS compared to ID individuals. In contrast, higher percentages of $\mathrm{CD} 8+\mathrm{T}$ cells; ratio $\mathrm{CD} 4$ :
Table 1 Serology in Down syndrome and intellectual disabilities

\begin{tabular}{|c|c|c|c|}
\hline Serology & $\begin{array}{l}\text { Down } \\
\text { syndrome(DS) } \\
(\%)\end{array}$ & $\begin{array}{l}\text { Intellectual } \\
\text { disabilities (ID) (\%) }\end{array}$ & $\begin{array}{l}p \\
\text { value* }^{*}\end{array}$ \\
\hline $\lg G(\mathrm{mg} / \mathrm{dl})$ & 25 & 5 & 0.13 \\
\hline $\operatorname{lgM}, \mathrm{mg} / \mathrm{dl}$ & 9 & 30 & 0.37 \\
\hline $\lg A, \mathrm{mg} / \mathrm{dl}$ & 41 & 15 & 0.11 \\
\hline $\mathrm{C} 3, \mathrm{mg} / \mathrm{dl}$ & 35 & 50 & 0.49 \\
\hline $\mathrm{C} 4, \mathrm{mg} / \mathrm{dl}$ & 28 & 11 & 0.36 \\
\hline $\mathrm{cRP}, \mathrm{mg} / \mathrm{l}$ & 21 & 52 & 0.06 \\
\hline ASO, UI/ml & 64 & 33 & 0.07 \\
\hline $\begin{array}{l}\text { Infectious monucleosis } \\
(\mathrm{lgG}), \text { UA/ml }\end{array}$ & 78 & 90 & 0.37 \\
\hline $\begin{array}{l}\text { Toxoplasmosis(lgG), } \\
\text { Ul/ml }\end{array}$ & 35 & 60 & 0.29 \\
\hline $\begin{array}{l}\text { HepatitisB (AntiHBS) } \\
\text { Ul/ml }\end{array}$ & 0 & 4 & 1 \\
\hline Measles (lgG), UI/ml & 100 & 100 & 1 \\
\hline Rubella (lgG), UI/ml & 71 & 89 & 0.36 \\
\hline $\begin{array}{l}\text { Cytomegalovirus(lgG), } \\
\mathrm{Ul} / \mathrm{ml}\end{array}$ & 78 & 79 & 1 \\
\hline
\end{tabular}

* Fisher test

CD8 was (1:1) and NK cells were detected on DS compared to ID individuals with significance difference $(\mathrm{p}<$ 0.05); (Table 2).

\section{3) Cytokine production}

The levels of IFN $\gamma$, TNF $\alpha$, IL-10 in the Down syndrome group (DS) were higher than in the intellectual Disabilities (ID) group $(\mathrm{p}<0.05)$. The median value of IFN $\gamma$ was $389.2 \mathrm{pg} / \mathrm{ml}$ in the Down syndrome group (DS) and $43.55 \mathrm{pg} / \mathrm{ml}$ in the Intellectual disabilities group (ID) with $\mathrm{p}=0.011$. The TNF $\alpha$ had medians (DS and ID) of $131.2 \mathrm{pg} / \mathrm{ml}$ and $37.38 \mathrm{pg} / \mathrm{ml}$, respectively, with $\mathrm{p}=$ 0.0071 and IL- 2 had medians of $68.40 \mathrm{pg} / \mathrm{ml}$ in DS and $23.55 \mathrm{pg} / \mathrm{ml}$ in ID, with $\mathrm{p}=n s$ (Figure 1). The median value of spontaneous IL-10 production was significantly higher in the DS group $(41.00 \mathrm{pg} / \mathrm{ml})$ when compared to the median value $(11.10 \mathrm{pg} / \mathrm{ml})$ in ID group with $\mathrm{p}=$

Table 2 Phenotype of peripheral blood mononuclear cells in Down syndrome and Intellectual disabilities individuals

\begin{tabular}{llll}
\hline Imunophenotype & $\begin{array}{l}\text { Down syndrome } \\
\text { (DS) } \mathbf{n}=\mathbf{1 9}\end{array}$ & $\begin{array}{l}\text { Intellectual } \\
\text { disabilities(ID) } \\
\mathbf{n}=\mathbf{2 0}\end{array}$ & $\begin{array}{l}\boldsymbol{p} \\
\text { value }\end{array}$ \\
\hline CD3 & $69.77 \pm 8.01$ & $64.86 \pm 10.53$ & 0.11 \\
CD4 & $40.96 \pm 12.68$ & $43.48 \pm 11.00$ & 0.51 \\
CD8 & $34.38 \pm 15.38^{*}$ & $22.47 \pm 8.78^{*}$ & 0.005 \\
CD19 & $3.63 \pm 2.54^{*}$ & $15.28 \pm 7.86^{*}$ & 0.001 \\
CD16 $^{+} / \mathrm{CD}^{*} 6^{+} / \mathrm{CD3}^{-}$ & $44.75 \pm 23.01^{*}$ & $29.19 \pm 15.41^{*}$ & 0.017 \\
CD14 $^{-}$ & $77.88 \pm 11.65$ & $84.15 \pm 9.987$ & 0.078 \\
\hline
\end{tabular}

${ }^{*}$ t test 


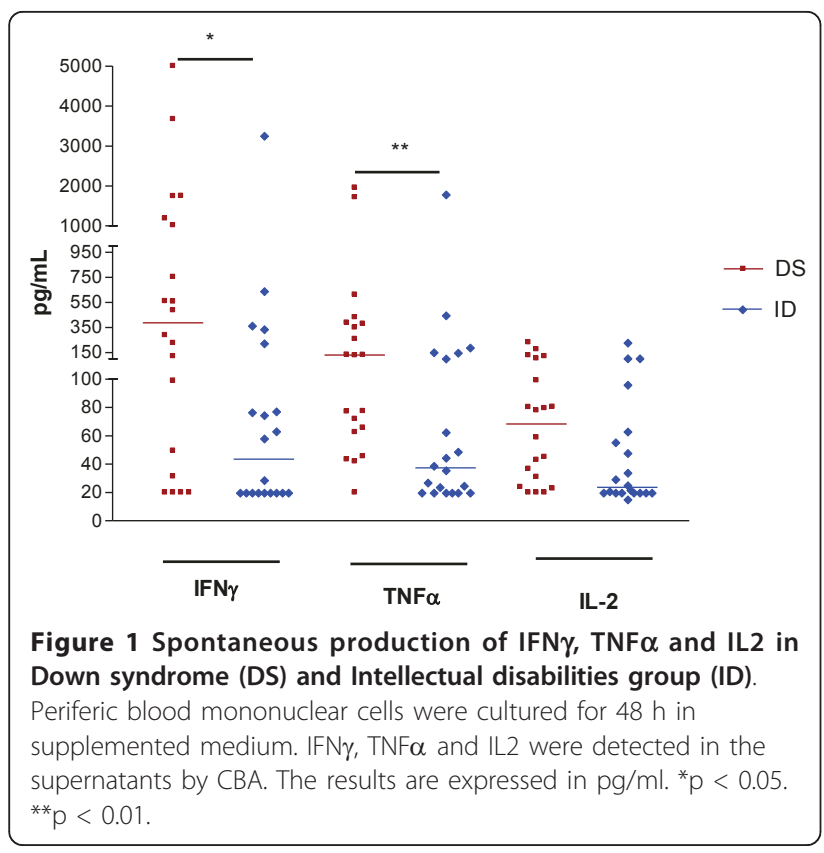

0.006; (Figure 2). Most samples from both groups (DS and ID) had spontaneous production of IL-4 and IL-5 with values below level of detection $(<20 \mathrm{pg} / \mathrm{mL})$.

\section{4) Relative Quantification of RCAN1 in PBMC}

We studied the expression of RCAN1 in PBMC. The data demonstrate neither negative regulation nor positive regulation of the gene RCAN1; with the medians of (DS and ID) 1.05 and 1.08 , respectively with $p=n s$; (Figure 3).

\section{Discussion}

In this study the humoral and cellular aspects of immune response were evaluated, as well as the

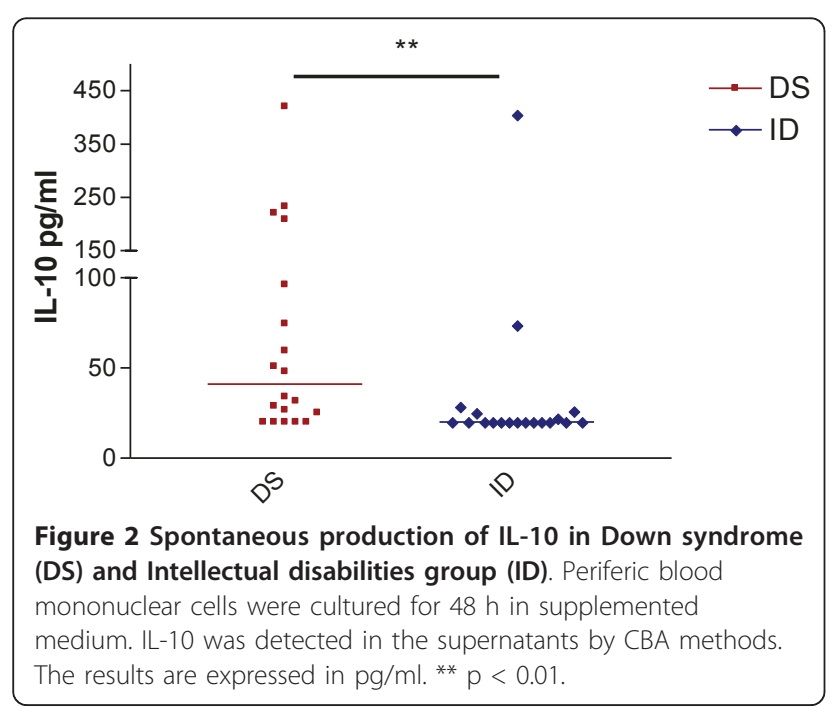

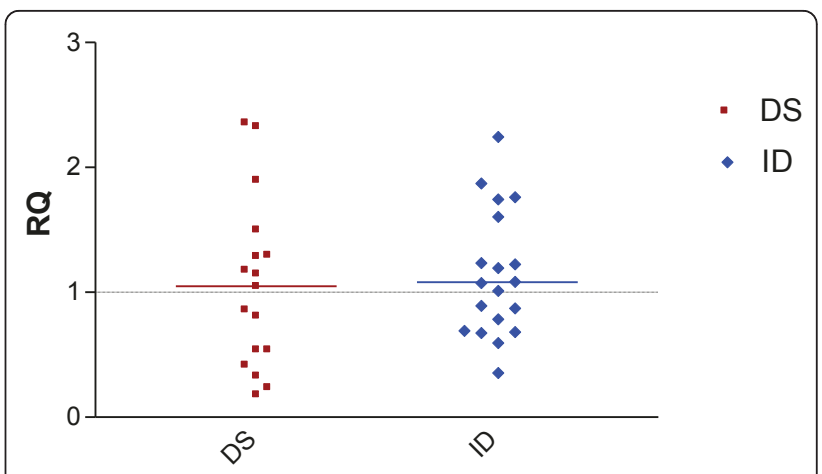

Figure 3 Relative quantification of RCAN1 in Down syndrome (DS) and Intellectual disability group (ID). The median in two groups (DS and ID) were respectively $(1.05 ; 1.08)$ with $p=n s$.

quantitative expression of the RCAN1 gene in a sample population of adults with DS and in an ID group without Down syndrome with a similar environmental condition. We sought to minimize the external and environmental factors influences.

The results show the humoral and cellular immune response aspects in adults with DS and with ID who were followed at APAE-SP. Since all individuals in this study live in the same community the immunological response differences are not due to the environmental condition.

In this study, the humoral immune response of $\operatorname{IgG}$, IgM, IgA immunoglobulin isotypes, complement factor, cRP, ASO, hepatitis B, cytomegalovirus, measles, rubella, toxoplasmosis, mononucleosis were similar in both groups. Some of the results are in line with the ones of other authors $[26,27,17,18]$ and they may reflect an adaptive mechanism in adults with Down syndrome in order to sustain an efficient response

The immunophenotypic findings in the DS group show increased numbers of NK cells and CD8+ T lymphocyte subpopulation with a ratio of 1:1 CD4:CD8, and decreased numbers of the B lymphocyte (CD19) percentages suggesting a predominance of cells of the innate immune response in DS [28]. Dietary antigens may represent a continuous stimulus for the immune system in this syndrome and interfere with normal immune responses [29].

This data also suggest early immunosenescence and accelerated apoptosis, preserving some subpopulations [9]. Many of these alterations are similar to those characteristic of chromosomally normal subjects of advanced age [30].

The fetal thymic development in the trisomy 16 (Ts16) mouse was examined, which is considered to be a model for human trisomy 21 . The Ts 16 thymus contains 10 to $20 \%$ of the number of lymphocytes found in a normal thymus at a comparable stage [31]. DS thymocytes have a markedly diminished proportion of cells 
expressing high levels of alpha, beta $\mathrm{T}$ cell receptor (alpha, beta TCR) and the associated CD3 molecule. In addition, DS subjects had a lower proportion of CD4 + CD45RA + cells representing naive $\mathrm{T}$ cells which have recently emigrated from the thymus [32].

Clinical relevance of this finding is not well established, considering that this immunophenotype is similar to what is found in 26 centenarians [30].

The major age-related modifications were the following: decreased absolute numbers of $\mathrm{T}$ lymphocytes (CD3 + ), involving both CD4+ and CD8+ subsets, accompanied by marked concomitant increased numbers of activated $\mathrm{T}$ cells $(\mathrm{CD} 3+$, HLA-DR+); marked decreased numbers of B lymphocytes (CD19+) with increase in some subclasses of immunoglobulin and an increase in the number of cells with markers of NK activity $[9,33]$.

Human immunosenescence represents a complex remodeling of the immunological system and it is induced by exposure to antigen and oxidative stress. There was a deterioration of the clonotypical immunity, while ancestral, innate immunity was largely preserved. In an aging immune system, adaptive immunity deteriorates because of a progressive decline of naive $\mathrm{T}$ and $\mathrm{B}$ cells and also due to a decrease of absolute numbers of $\mathrm{T}$ and $\mathrm{B}$ lymphocytes. The innate compartment of the immune system is relatively well preserved although some age-dependent alterations can be also observed [30]. Aging is characterized by a peculiar chronic inflammatory status also called 'inflammaging', resulting in cellular and molecular activation, that allows the organism to respond to multiple stress present during the process of aging [30,34].

These data suggest that there is an early immunosenescence probably due to accelerated apoptosis, preserving some subpopulations $[9,34,35]$.

Studies of the T-cell phenotype and function have frequently resulted in conflicting outcomes, the overall evidence strongly pointed to a primary and profound impairment of T-cell mediated immunity [36].

Moreover, the relative and the absolute size of apoptotic CD3+ T lymphocytes, and the relative size of apoptotic CD19+ B lymphocytes were significantly higher in DS children than in controls $[9,36]$.

Several lines of evidence suggest that telomere shortening plays a causal role in cellular aging. If this were true and if telomere shortening plays a role in cellular aging, then one might predict critically shortened telomeres in the lymphocytes of these individuals. It was found that, in DS, the rate of telomere loss in peripheral blood lymphocytes was three times higher than that in age-matched normal donors [37].

In this study the normal immunoglobulin level outcomes, in spite of decreased CD19, indicate an adaptative mechanism.
There are a very few studies about cytokines in DS. Studies in children give evidence that the DS thymus has lower number of phenotypically mature thymocytes, which express high levels of the $\mathrm{T}$ cell receptor and associated CD3-molecule [38].

Furthermore, there were high levels of tumor necrosis factor (TNF $\alpha$ ) and interferon (IFN $\gamma$ ) cytokines that suggest a deregulation in cytokine production in DS and it may also provide an explanation for the abnormal thymic anatomy and the thymocyte maturation [32]. In adults, high percentages of IFN $\gamma$ (Th1) were found, and the Th1/Th2 ratio was higher in DS patients than in controls [39]. The elevated production of IFN $\gamma$, TNF $\alpha$ and IL-10 was not followed by IL-2 production that has Th1 profile [40]. These cytokines' production can be likely due to the macrophage and to the NK cells and are not produced by $\mathrm{T}$ cells.

The plasmatic high levels of pro-inflamatory cytokines in DS patients are due to endothelial activation without the activation of the immune responses [41,42]

There are a very few studies focused in cytokines production in these populations, and none of them link the production of cytokines to RCAN1's overexpression in peripheral blood mononuclear cells.

The overexpression of the RCAN1 gene has already been observed in several tissues, particularly in the human brain, the spinal cord, the kidney, the liver, the mammary glands, the placenta, the skeletal muscles and the heart. In adults, RCAN1 isoform 1 is most highly expressed in the heart, the brain, the muscles and the pancreas, while isoform 4 is most highly expressed in the heart, the liver, the muscles, the placenta, the pancreas and the kidney. The expression of isoform 2 was detected in fetuses $[22,43,44]$. The RCAN1 is involved in the regulation of various cellular functions [23]. It is overexpressed in the brains of DS fetuses and in postmortem brain samples of AD patients [20,44]. RCAN1 has also been implicated in cardiac valve formation and in inhibition of cardiac hypertrophy [25]. RCAN1, induced by VEGF, TNF- $\alpha$, and calcium ionophore, participates in the endothelial cell migration and in the angiogenesis, showing the existence of several regulatory mechanisms [45,46,28].

In this study we used a fragment that includes exon 5 to exon 7 which are present in all isoforms. There are two hypotheses to relate phenotype to gene expression in chromosome 21. Theoretically, the supernumerary copy of human chromosome 21 (HSA21) is expected to result in an increase in the level of transcripts of all genes mapping to HSA21. However, it has been recently observed that there is not always a direct correlation between genomic imbalance (deletion or duplication) and transcript level of genes within the aneuploid segment, suggesting that complex molecular mechanisms 
regulate RNA transcript levels $[47,48]$. Due to this reason, many studies have been trying to clear the mechanism that leads to the expression of these genes [49]. A study established that genes in chromosome 21, expressed 1.5 times, would be superexpressed. In respect to gene RCAN1, this finding concludes that an expression under 1.5 indicates that the gene has compensatory mechanisms; in other words, it is influenced by or interacts with other genes [50]. The findings in this study, show that the RCAN1's relative expression is about 1 , suggesting that the gene does not interfere in the DS phenotype, which was studied in peripheral blood mononuclear cells. Relative expression of RCAN1 showed neither positive nor negative regulation on the calcineurin pathway and on the production of cytokines.

Maybe other ethics models of study would be necessary with specific stimulus or which would be synergic with other genes to demonstrate the overexpression of RCAN1 in vivo.

\section{Conclusion}

These data suggest a similar humoral response in both groups. In adults with Down's syndrome, the immunophenotypic alterations could be attributed the signals of precocious immunosenescence in the immune system. There is predominance of the Th1 profile in cytokines' production without any apparent relation with the RCAN1's expression in the PBMC. The overexpression of RCAN1 in PBMC was not observed. This study stimulates the evaluation of new ways of studying these genes according to the types of specific stimuli as well as new ways of assessing the influence or interaction with other genes.

\section{Materials and methods Population}

The studied population included adults with Down syndrome (DS) or with intellectual disability but without Down syndrome (ID), who were being followed at the same Institution (Associação de Pais e Amigos dos Excepcionais - APAE-SP), and who were living in a similar environmental condition. The blood samples were obtained from 24 patients (DS) with karyotype free of trisomy and 21 patients (ID) without Down syndrome confirmed by karyotype. Mean ages were $38 \pm 8,7$ years for DS and $43 \pm 8,3$ years for ID. The collection procedures were approved by the Heart Institute Ethics Committee (Heart Institute, Clinical Hospital, University of São Paulo (HC-FMUSP). The selected patients and/or those responsible for them were informed, in a clear and detailed way, about the objectives of the research and the procedures to be carried out, as well as about the risks, discomforts and benefits, and they signed the Terms of a free, prior and informed Consent.

\section{Serology}

The antibodies to hepatitis B (by MEIA), cytomegalovirus, infectious mononucleosis, toxoplasmosis, rubella (by ELISA), measles (by IFI), and anti-streptolysin O (ASO) were all investigated. the $\mathrm{C}$-reactive protein (cRP), the Complement factors C3, C4, (by nephelometry) and immunoglobulin isotypes IgG, IgM, IgA (by immunoturbidimetric assay) present in the serum from the individuals of the study were also investigated. All serology was performed by the Central Laboratory of Heart Institute, Clinical Hospital, University of São Paulo.

\section{Cellular Separation and Cell freezing}

The venous blood was collected into heparinized tubes $(20 \mathrm{~mL})$ and the separation of the peripheral blood mononuclear cells (PBMC) was obtained with FicollHypaque gradient [51]. A total of 4-5 $\times 10^{6} \mathrm{cells} / \mathrm{ml}$ were frozen in appropriate volume of freezing media $(10 \%$ dimethyl sulphoxide - DMSO, and 90\% fetal calf serum, FCS) for posterior flow cytometry analysis.

\section{Cellular Culture}

Peripheral blood mononuclear cells $\left(5 \times 10^{6}\right.$ cells $)$ were cultured in DMEM (Sigma) containing $20 \%$ of fetal calf serum (FCS). After 48 hours the culture supernatants were collected to measure the cytokine production: IL-2, IL-4, IL-5, IL-10, TNF $\alpha$ and IFN $\gamma$.

\section{Cytokine production}

Cytokines in culture supernatants were quantified by immunofluorescent flow cytometry (FASCalibur flow cytometer, Becton Dickinson, California, USA) using Human Chemokine and Th1/Th2 Cytokine Cytometric Bead Array (CBA) reagent kits (BD Biosciences Pharmingen, California, USA) according to the manufacturer's instructions. The production of IL-2, IL-4, IL-5, IL-10, TNF $\alpha$ and IFN $\gamma$ cytokines was quantified. The results were based on a standard concentration curve established between 5000 and $20 \mathrm{pg} / \mathrm{ml}$.

\section{Flow cytometry analysis}

The PBMC cells were thawed and washed for posterior Flow cytometry analysis. The purified PBMC (4-6 $\times$ $10^{6}$ cells) were incubated with a panel of fluorochromeconjugated mAbs. Cells were analyzed using anti-CD8 and andi-CD16-fluorescein isothiocyanate (FITC) (BD Biosciences Pharmingen) anti-CD4, anti-CD19, antiCD14 and anti-CD56-phycoerythrin (PE) (BD Pharmingen), anti-CD3-indotricarbocyanine coupled with phycoerythrin (PE-Cy5) (BD Pharmingen) monoclonal antibodies. Events $\left(10 \times 10^{3}\right)$ gated were analyzed using a FACScalibur flow cytometer and CellQuest software (Becton-Dickinson, Mountain View, CA). The population 
region (lymphocyte and monocyte gate) was set manually, based on the forward-scatter and side-scatter characteristics. The relative count of each subpopulation was expressed as a percentage within the total population.

\section{Quantitative Real-Time PCR (QT-PCR) for RCAN1 gene expression}

Total RNA from PBMC was extracted using the Trizol ${ }^{\circledR}$ method (Life Technologies Inc., Grand Island, NY). RNA quantities were determined by A260 measurement and the integrity of the RNA was confirmed by gel electrophoresis. One microgram of total RNA was used for the cDNA synthesis. Briefly, $1 \mu \mathrm{g}$ of total RNA total, 1 $\mu \mathrm{l}$ oligodT $(500 \mu \mathrm{g} / \mathrm{ml}), 1 \mu \mathrm{l}$ dNTP $(10 \mathrm{mM}$ of dATP, dCTP, dGTP and dTTP), DEPC water q.s.p. $12 \mu \mathrm{l}$, the reaction was conducted for $5 \mathrm{~min}$ at $40^{\circ} \mathrm{C}$. After this 4 $\mu \mathrm{l}$ Transcription Buffer $5 \mathrm{x}$ was added (Tris- $\mathrm{HCl} 250$ $\mathrm{mM} \mathrm{pH} \mathrm{8,3,} \mathrm{KCl} 375 \mathrm{mM}, \mathrm{MgCl} 215 \mathrm{mM}), 2 \mu \mathrm{l}$ DT 0,1 M, $1 \mu \mathrm{l}$ inhibitor RNase (40 U/ $\mu \mathrm{l})$ (RNAse OUT ${ }^{\mathrm{TM}}$, Invitrogen, Carlsbad, CA, EUA) and $1 \mu$ l Super-script II ${ }^{\mathrm{TM}}$ Reverse Transcriptase $(200 \mathrm{U} / \mu \mathrm{L})$ (Invitrogen, Carlsbad, CA, EUA), the reaction was heated for $50 \mathrm{~min}$ at $42^{\circ} \mathrm{C}$ and $15 \mathrm{~min}$ at $70^{\circ} \mathrm{C}$.

The sequences of primers for QT-PCR were designed using Primer Express (PE Applied Biosystems, Foster City, CA, USA). The following primer sequences were used: RCAN1 (Acc. no. NM_203417) sense 5'-CAGTTTCTGATCTCCCCTCC-3', anti-sense 5'-TCATACTTTTCCCCTGGCCC-3' and Glyceraldehyde-3phosphate dehidrogenase (GAPDH; Acc. no. M33197) sense 5'-TGGTCTCCTCTGACTTCAACA-3', anti-sense 5'-AGCCAAATTCGTTGTCATACC-3'. The primer sequence design for the RCAN1 gene was performed covering exons 5, 6 and 7 which are constant in all the isoforms of the gene. Real-time PCR reactions were carried out in an ABI Prism 7500 Sequence Detection system (PE Applied Biosystems, Foster City, CA, USA). QT-PCR was performed using the SYBR Green PCR Master Mix (PE Applied Biosystems), according to the manufacturer's instructions. Quantities of specific mRNA in the sample were measured according to the corresponding gene-specific standard curve. All the samples were tested in triplicate with the reference gene GAPDH, a housekeeping gene for normalization of data. For all genes we constructed standard curves and determined the slope to calculate the PCR efficiency according to Pfaffl; (data not show) [52,53]. Normalization and fold change were calculated with the $\Delta \Delta \mathrm{Ct}$ method with GAPDH as the reference mRNA [54].

\section{Statistical Analysis}

Statistical analysis was performed by AlphPrism 3.0 and SPSS 16 software. For continuous data with normal distribution, the impaired $\mathrm{T}$ test was used. For data which do not include normal distribution, the Mann Whitney test was used. For categorical data, the Fisher test or
Chi-square test were used. Statistical significance was given for $\mathrm{p}<0.05$.

\section{List of abbreviations}

AD: Alzheimer disease; DS: Down syndrome; IgG: ImmunoglobulinG; IgA: Immunoglobulin A; IgM: Immunoglobulin M; ID: Intellectual Disabilities; NK: Natural Killer; PBMC: Peripheral blood mononuclear cells; HSA21: Trisomy of chromosome 21; RCAN1: The regulator of calcineurin 1 gene; NFATs: The nuclear factors of activated T cells; ASO: Streptolysin A; IFNY: IFNgamma: $\gamma$ Interferon; TNFa: Tumor necrosis factor a: TNFalpha

\section{Author details}

${ }^{1}$ Heart Institute University of São Paulo Medical School, São Paulo. ${ }^{2}$ Albert Einstein Hospital, São Paulo.

\section{Authors' contributions}

MBFT; ACG: carried out the molecular genetic studies, participated in the sequence alignment and drafted the manuscript. MBFT; SGF: carried out the immunoassays.

MBFT; ACG: participated in the sequence alignment.

MBFT; JBS: participated in the design of the study and performed the statistical analysis.

JEK; JBSA; MW; ACG conceived of the study, and participated in its design and coordination.

All authors read and approved the final manuscript.

\section{Competing interests}

The authors declare that they have no competing interests.

Received: 10 October 2010 Accepted: 16 April 2011

Published: 16 April 2011

\section{References}

1. Yang Q, Rasmussen SA, Friedman JM: Mortality associated with Down's syndrome in the USA from 1983 to 1997: a population-based study. Lancet 2002, 359:1019-25.

2. Hasle $\mathrm{H}$, Clemmensen $\mathrm{H}$, Mikkelsen M: Risks of leukaemia and solid tumours in individuals with Down's syndrome. Lancet 2000, 355:165-69.

3. Licastro F, Marocchi A, Penco S, Porcellini E, Lio D, Dogliotti G, Corsi MM: Does Down's syndrome support the homocysteine theory of atherogenesis? Arch Gerontol Geriatr 2006, 43(3):381-7.

4. Ylä-Herttuala S, Luoma J, Nikkari T, Kivimäki T: Down's syndrome and atherosclerosis. Atherosclerosis 1989, 76(2-3):269-72.

5. Murdoch JC, Rodger JC, Rao SS, Fletcher CD, Dunnigan MG: Down's syndrome: an atheroma free-model? British Medical Journal 1977, 2:226-228

6. Dogliotti G, Galliera E, Licastro F, Corsi MM: Age-related changes in plasma levels of BDNF in Down syndrome patients. Immunity \& Ageing 2010, 7:2.

7. Cuadrado E, Barrena MJ: Immune dysfunction in Down syndrome: primary immune deficiency or early senescence of the immune system? Clin Immunol Immunopathol 1996, 78:209-14.

8. Yasui K, Shinozaki K, Nakazawa T, Agematsu K, Komiyama A: Presenility of granulocytes in Down syndrome individuals. Am J Med Genet 1999, 84:406-12

9. Corsi MM, Ponti W, Venditti A, Ferrara F, Baldo C, Chiappelli M, Licastro F: Proapoptotic activated T-cells in the blood of children with Down's syndrome: relationship with dietary antigens and intestinal alterations. Int J Tissue React 2003, 25(3):117-25.

10. Li Volti S, Mattina T, Mauro L, Bianca S, Anfuso S, Ursino A, Mollica F: Safety and effectiveness of an acellular pertussis vaccine in subjects with Down's syndrome. Child Nerv Syst 1996, 12:100-2.

11. McKay E, Hems G, Massie A, Moffat MA, Phillips KM: Serum antibody to poliovirus in patients in a mental deficiency hospital, with particular reference to Down's syndrome. J Hyg (Lond) 1978, 81:25-30.

12. Epstein $L B$, Philip R: Abnormalities of the immune response to influenza antigen in Down syndrome (trisomy 21). Prog Clin Biol Res 1987, 246:163-82.

13. Philip R, Berger AC, McManus NH, Warner NH, Peacock MA, Epstein LB: Abnormalities of the in vitro cellular and humoral responses to tetanus 
and influenza antigens with concomitant numerical alterations in lymphocyte subsets in Down syndrome (trisomy 21). J Immunol 1986, 136:1661-7.

14. Costa-Carvalho BT, Martinez RM, Dias AT, Kubo CA, Barros-Nunes P, Leiva L, Solé D, Carneiro-Sampaio MM, Naspitz CK, Sorensen RU: Antibody response to pneumococcal capsular polysaccharide vaccine in Down syndrome patients. Braz J Med Biol Res 2006, 39:1587-92

15. Ferreira CT, Leite JC, Taniguchi A, Vieira SM, Pereira-Lima J, da Silveira TR: Immunogenicity and safety of an inactivated hepatitis A vaccine in children with Down syndrome. J Pediatr Gastroenterol Nutr 2004, 39:337-40.

16. Hawkes RA, Boughton CR, Schroeter DR: The antibody response of institutionalized Down's syndrome patients to seven microbial antigens. Clin Exp Immunol 1978, 31:298-304.

17. Troisi $\mathrm{CL}$, Heiberg DA, Hollinger FB: Normal immune response to hepatitis $B$ vaccine in patients with Down's syndrome. A basis for immunization guidelines. JAMA 1985, 254:3196-9.

18. do Canto CL, Granato CF, Garcez E, Villas Boas LS, Fink MC, Estevam MP, Pannuti CS: Cytomegalovirus infection in children with Down syndrome in a day-care center in Brazil. Rev Inst Med Trop Sao Paulo 2000, 42:179-83.

19. Murphy M, Insoft RM, Pike-Nobile L, Epstein LB: A hypothesis to explain the immune defects in Down syndrome. Prog Clin Biol Res 1995, 393:147-67.

20. Roberts-Thomson IC, Whittingham S, Youngchaiyud U, MacKay IR: Ageing, immune response and mortality. Lancet 1974, 2:368.

21. Martin GM: Genetic modulation of senescent phenotypes in Homo sapiens. Cell 2005, 120(4):523-32.

22. Fuentes JJ, Genesca L, Kingsbury TJ, Cunningham KW, Perez-Riba M, Stivill X, la Luna S: DSCR1 overexpressed in Down syndrome, is an inhibitor of calcineurin-mediated signaling pathways. Human Molecular Genetics 2000, 11(9):1681-90.

23. Harris CD, Ermak G, Davies KJ: DSCR1 (Adapt78 or RCAN1) in disease. Cell Mol Life Sci 2005, 62:2477-2486

24. Fruman DA, Klee CB, Bierer BE, Burakoff SJ: Calcineurin phosphatase activity in T lymphocytes is inhibited by FK 506 and cyclosporin A. Proc Natl Acad Sci USA 1992, 89:3686-90.

25. Yang J, Rothermel B, Vega RB, Frey N, McKinsey TA, Olson EN, BasselDuddy R, Williams RS: Independent signals control expression of the calcineurin inhibitory proteins MCIP1 and MCIP2 in striated muscles. Circ Res 2000, 87:E61-68.

26. Burgio GR, Ugazio AG, Nespoli L, Marcioni AF, Bottelli AM, Pasquali F: Derangements of immunoglobulin levels, phytohemagglutinin responsiveness and T and B cell markers in Down's syndrome at different ages. Eur J Immunol 1975, 5:600-3.

27. Seger R, Buchinger $G$, Ströder J: On the influence of age on immunity in Down's syndrome. Eur J Pediatr 1977, 124:77-87.

28. Cossarizza A, Monti D, Montagnani G, Ortolani C, Masi M, Zannotti M, Franceschi C: Precocious aging of the immune system in Down syndrome: alterations of B lymphocytes, T-lymphocyte subsets, and cells with natural killer markers. Am J Med Genet Suppl 1990, 7:213-8.

29. Licastro F, Mariani RA, Faldella G, Carpenè E, Guidicini G, Rangoni A, Grilli T, Bazzocchi G: Immune-endocrine status and coeliac disease in children with Down's syndrome: relationships with zinc and cognitive efficiency. Brain Res Bull 2001, 55(2):313-7.

30. Franceschi $\mathrm{C}$, Bonafè $\mathrm{M}$ : Centenarians as a model for healthy aging. Biochem Soc Trans 2003, 31:457-61.

31. Ewart $\mathrm{LL}$, Auerbach R: Defects in thymocyte differentiation and thymocyte-stromal interactions in the trisomy 16 mouse. Dev Immunol 1992, 2.215-26.

32. Murphy M, Friend DS, Pike-Nobile L, Epstein LB: Tumor necrosis factor alpha and IFN-gamma expression in human thymus. J Immunol 1992 149:2506-12.

33. Sansoni P, Cossarizza A, Brianti V, Fagnoni F, Snelli G, Monti D, Marcato A, Passeri G, Ortolani C, Forti E, Fagiolo U, Passeri M, Franceschi C: Lymphocyte Subsets and Natural Killer Cell Activity in Healthy Old People and Centenarians. Blood 1993, 82:2767-73.

34. Elsayed SM, Elsayed GM: Phenotype of apoptotic lymphocytes in children with Down syndrome. Immunity \& Ageing 2009, 6:2.

35. Kaszubowska L: Telomere shortening and ageing of the immune system. J Physiol Pharmacol 2008, 59(Suppl 9):169-86.
36. Ugazio AG, Maccario R, Notarangelo LD, Burgio GR: Immunology of Down syndrome: A review. Am J Med Genet 1990, 204-12.

37. Vaziri H, Schächter F, Uchida I, Wei L, Zhu X, Effros R, Cohen D, Harley CB: Loss of telomeric DNA during aging of normal and trisomy 21 human lymphocytes. Am J Hum Genet 1993, 52:661-7.

38. Murphy M, Lempert MJ, Epstein LB: Decreased level of T cell receptor expression by Down syndrome (trisomy 21) thymocytes. Am J Med Genet 1990, 7:234-7.

39. Franciotta D, Verri A, Zardini E, Andreoni L, De Amici M, Moratti $\mathrm{B}$ Nespoli L: Interferon-gamma- and interleukin-4-producing T cells in Down's syndrome. Neurosci Lett 2006, 395:67-70.

40. Lio D, Candore G, Crivello A, Scola L, Colonna-Romano, Cavallone L, Hoffmann E, Caruso M, Licastro F, Caldarera CM, Branzi A, Francheschi C, Caruso C: Opposite effects of interleukin 10 common gene polymorphisms in cardiovascular diseases ans in sucessful ageing: genetic background of male centenarians is protective against coronary heart disease. J Med Genet 2004, 41:790-94.

41. Licastro F, Chiappelli M, Porcellini E, Trabucchi M, Marocchi A, Corsi MM Altered vessel signalling molecules in subjects with Down's syndrome. Int J Immunopathol Pharmacol 2006, 19(1):181-5.

42. Licastro F, Chiappelli M, Ruscica M, Carmelli V, Corsi MM: Altered cytokine and acute phase response protein levels in the blood of children with Down syndrome. Int I Immunopathol Pharmacol 2005, 18:165-172.

43. Fuentes JJ, Pritchard MA, Estivill X: Genomic organization, alternative splicing and expression patterns of the DSCR1 (Down syndrome candidate region 1) gene. Genomics 1997, 44:358-361.

44. Ermak G, Morgan TE, Davies KJ: Chronic overexpression of the calcineurin inhibitory gene DSCR1 (Adapt78) is associated with Alzheimer's disease. J Biol Chem 2001, 276:38787-94.

45. Lizuka M, Abe M, Shiiba K, Sasaki I, Sato Y: Down syndrome candidate region 1, a downstream target of VEGF, participates in endothelial cell migration and angiogenesis. J Vasc Res 2004, 4:334-44.

46. Kim YS, Cho KO, Lee HJ, Kim SY, Sato Y, Cho YJ: Down Syndrome Candidate Region 1 Increases the Stability of the IkBa Protein. IMPLICATIONS FOR ITS ANTIIINFLAMMATORY EFFECTS*. The Journal of Biological Chemistry 2006, 281:39051-61.

47. Saran NG, Pletcher MT, Natale JE, Cheng Y, Reeves RH: Global disruption of the cerebellar transcriptome in a Down syndrome mouse model. Hum Mol Genet 2003, 12:2013-19.

48. Shapiro BL: Developmental instability of the cerebellum and its elevance to Down syndrome. J Neural Transm 2001, 61(Suppl):11-34

49. Patterson D: Molecular genetic analysis of Down syndrome. Hum Genet 2009, 126:195-214

50. Ait Yahya-Graison E, Aubert J, Dauphinot L, Rivals I, Prieur M, Golfier G, Rossier J, Personnaz L, Creau N, Bléhaut H, Robin S, Delabar JM, Potier MC Classification of human chromosome 21 gene-expression variations in Down syndrome: impact on disease phenotypes. Am J Hum Genet 2007, 81:475-91

51. Boyum A: Separation of blood leucocytes, granulocytes and lymphocytes. Tissue Antigens 1974, 4:269-74.

52. Pfaffl MW: A new mathematical model for relative quantification in realtime RT-PCR. Nucleic Acids Res 2001, 29:e45.

53. Pfaffl MW, Horgan GW, Dempfle L: Relative expression software tool (REST) for group-wise comparison and statistical analysis of relative expression results in real-time PCR. Nucleic Acids Res 2002, 30:e36.

54. Livak KJ, Schmittgen TD: Analysis of relative gene expression data using real-time quantitative PCR and the 2 (-Delta Delta $C(T)$ ) Method. Methods 2001, 25:402-8

doi:10.1186/1742-4933-8-4

Cite this article as: Trotta et al: Inflammatory and Immunological

parameters in adults with Down syndrome. Immunity \& Ageing 2011 8:4. 